\title{
UNIVERSUM AFTER 32 YEARS OF ITS FOUNDATION: BIBLIOMETRIC AND RELATIONAL ANALYSIS
}

\author{
Universum después de 32 años de su fundación: análisis bibliométrico y \\ relacional
}

\author{
Yerco Uribe-Bahamonde* \\ Claudio Díaz Herrera**
}

\begin{abstract}
In the following paper, a bibliometric and relational analysis had been was carried out on the Universum journal from its date of foundation (1986) to the present (2017). A database had been was prepared with all the publications of the journal (47 issues in 32 years), with a total sample of 765 publications. Bibliometric, collaborative indicators (Subramanyam, Lawani and, coefficient of collaboration) we had been applied, relationships were analyzed, both at the level of countries and Chilean institutions, as well as the participation by sex in the different years. The results show that the largest number of documents are produced by only one author $(84 \%)$, and led mainly by male authors $(71.3 \%)$. We can see a balance in the number of authors both male and female in the years 2000-2002. The country with the highest production within the journal is Chile, while the institutions that contribute the most and generate collaboration links are the University of Talca, University of Santiago de Chile and the University of Chile. This analysis allows representing the history and tendency of the journal at the level of authors and authors relationships.
\end{abstract}

Keywords: bibliometric, authors relationship, journal.

* Doctoral student in Human Sciences, Psychology Faculty and Institute of Humanistic Studies “Juan Ignacio Molina”, University of Talca. Talca, Chile. Email: yuribe@utalca. cl / ORCID: 0000-0002-1791-404X

** Doctoral student in Human Sciences, Psychology Faculty and Institute of Humanistic Studies “Juan Ignacio Molina”, University of Talca. Talca, Chile. Email: cldiaz@utalca. cl / ORCID: 0000-0001-7369-4160

Article received on January 16, 2019. Accepted on March 13, 2019. 


\section{RESUMEN}

En el siguiente artículo se realizó un análisis bibliométrico y relacional a la revista Universum desde la fecha de fundación (1986) hasta la actualidad (2017). Para ello se elaboró una base de datos con la totalidad de publicaciones de la revista (47 números en 32 años), con una muestra total de 765 publicaciones. Se aplicaron indicadores bibliométricos, de colaboración (Subramanyam, Lawani y coeficiente de colaboración), se analizó las relaciones, tanto a nivel de países como de instituciones chilenas, así como la participación por sexo en los distintos años. Los resultados evidencian que la mayor cantidad de documentos son elaborados por solo un autor (84\%) el cual es liderado principalmente por autores masculinos $(71.3 \%)$. Se puede ver un equilibrio en la cantidad de autores tanto femeninos como masculinos en los años 2000-2002 y el país con mayor producción dentro de la revista es Chile. Las instituciones que más aportan y generan vínculos de colaboración son la Universidad de Talca, Universidad de Santiago de Chile y la Universidad de Chile. Este análisis permite representar la historia y tendencia de la revista a nivel de autores y relaciones.

Palabras clave: bibliometría, relaciones, revista.

\section{Introduction}

Numerous studies have tried to explain and denote the existence of collaborations among scientific publications. Scientific journals can originate from different necessities. Amongst the most common ones there is the interest in communicating the results of a research in a simple manner, as well as the capability to create critical discussion spaces. Nowadays, scientific journals have become a reliable channel for the communication of research articles, since it is assumed that the contents of such have been assessed thoroughly by the scientific community (Salas et al., 2017).

Publication itself allows to differentiate perspectives in determined fields of knowledge, which enables the reader to either agree or disagree with an article, to reference it, criticize it, and even, more importantly: get inspiration and new ideas from the previous researches, simultaneously generating new publications (Polanco-Carrasco, 2015).

New technologies for information and communication have changed the main paradigm in scientific publications and research. The internet, in 
this context, has become (for the scientific world) a new way of showing a great spectrum of contents and data that are accessible at a lower cost than printed hard-copies of papers (Wren, 2005). Moreover, the internet provides with immediate diffusion at a low cost, while adding values of storage, processing, search and analysis in a more exact manner (Rodríguez Piña, 2006). Bibliometric analyses use this same data, aiming to quantitatively identify nexus of collaboration, quantity and reference projection, theme aggrupation, methodology uses, resource sources, author gender, among other aspects (Reutzel \& Mohr, 2015).

New technologies for information and communication have changed the main paradigm in scientific publications and research. The internet, in this context, has become (for the scientific world) a new way of showing a great spectrum of contents and data that are accessible at a lower cost than printed hard-copies of papers (Wren, 2005). Moreover, the internet provides with immediate diffusion at a low cost, while adding values of storage, processing, search and analysis in a more exact manner (Rodríguez Piña, 2006). Bibliometric analyses use this same data, aiming to quantitatively identify nexus of collaboration, quantity and reference projection, theme aggrupation, methodology uses, resource sources, author gender, among other aspects (Reutzel \& Mohr, 2015).

The concept of bibliometrics has changed since in $1922 \mathrm{E}$. Wyndham Hulme first used the term "statistical bibliography", after presenting two conferences that would later on become a book (Hulme, 2015). In 1930, the concept evolved into "the science of science" (Garfield, 2009; 2006), and in 1955 the first reference analysis "citation index entry" is introduced (Garfield, 1955), with a similar scheme to the Beilstein compendium (Taylor, 1948), thus generating a new scenario for the work of scientific research. In 1962, Gross and Pritchard replace the term "statistical bibliography" with the concept of "bibliometrics". The authors proposed bibliometrics has the mission of applying both mathematics and statistical methods to show the course and development of the scientific disciplines (Lawani, 1981; Gross \& Pritchard, 
1969).

In Hispanic America, several bibliometric analyses have been done with diverse journals, such as: studies over the professional trajectory and access to directive positions in women (Selva, Sahagúnl, \& Pallarès, 2011), scientific productivity and collaboration in viticulture and enology in Latin-American countries (Aleixandre, Bordeu, Aleixandre-Tudó, Bolaños \& AleixandreBenavent, 2013), analysis of the south American research in sport sciences (Andrade, López, Ramírez-Campillo, Beltrán, R. \& Rodríguez, 2013), or some specific ones as: short-term impact of the Chilean journal of agricultural research (Krauskopf, 2012), most relevant Iberic-American journals related to clinical psychology and health (Ariza y Granados, 2012), scientific production and the use of the Chilean Nutrition Journal (Tomás-Casterá, Sanz-Valero, y Wanden-Berghe, 2010), impact and visibility of the Chilean Surgery Journal after its indexation to SciELO and ISI databases (Cartes-Velásquez, Moraga, Aravena y Manterola, 2012), Bliliometric analysis of the Psykhe Journal celebrating its 25 years of trajectory (Salas et al., 2017) or the Mexican study that analyzes the initial stage of the Mexican Politic Sciences Journal upon 60 years of its foundation (Olvera, 2016).

This publication presents a bibliometric analysis of the Universum ${ }^{1}$ Journal of Humanities and Social Sciences, edited and directed by the Institute of Humanistic Studies Juan Ignacio Molina of the University of Talca. The journal is indexed in the SciELO Chile, SCOPUS, LATINDEX, EBSCO, PROQUEST, DIALNET and REDALYC databases (McBride, 2009). Currently, it is located in the 3th quartile (Q3) in the category of Arts and Humanities (miscellaneous) and Social Sciences (miscellaneous), presenting an $\mathrm{H}$ index of 7, according to the Scimago records (Scimago Journal \& Country Rank, 2018). The aforementioned terms are characteristics that journals must have in order to be considered as main current journals (Valderrama, 2012), as the ones recognized by Web of Science, previously the Institute for Scientific Information (ISI) (Krauskopf \& Vera, 1995). The journal has been edited

\footnotetext{
${ }^{1}$ ISSN: 0716-498X en su versión impresa e ISSN: 0718-2376 en su versión electrónica.
} 
continuously and uninterruptedly, publishing a volume every six months to this day. Nevertheless, the journal was published annually from the first to the 18 th issue (with the exception of issues 2 and 3 ).

Finally, it is worth mentioning that no bibliometric analysis has been done with Universum. As to honor the director of this particular journal, the late Dr. Javier Pinedo, and celebrate over three decades of edition, the present paper aims to answer the following questions: what has been the historical path of Universum? How has the participation of men and women been in it? How and when has there been collaboration between the participant countries and institutions? This all as a mean to help consolidate the aforementioned journal even more in the national and international academia.

\section{History of Universum}

Starting from the first issue of Universum, its founder Vittorio Di Girolamo planned publications universal in character. He argued that "the essence of all ideas, studies, experiments, works and experiences were particular to the essence of the human creature, to talk about Universum is established as the main truth: the union of the diverse" (Di Girólamo, 1986: 1). This is synthesized in a multidisciplinary journal, attending primarily to the publication interests that the different Institutes and Faculties of the University of Talca had at the time (Pinedo, 1998). In 1966, in the 11th edition of the journal, it was decided to modify the presentation or the articles, updating its format to have a more academic approach: the traditional two-column format is eliminate, as a mean to favor text over the use of pictures (Pinedo, 1996).

In 2000, Javier Pinedo highlights the direction of the journal through its publications, as being: "acknowledged among Chilean, Latin-American and international academics, who are interested in the study of culture, history and thought" (Pinedo, 2000: 8). Nowadays, we can state that the dimensions of the journal can be grouped in four categories: "Humanism and letters $(35,4 \%)$; social, political and cultural theory (28\%); administration and economic development (12,3\%); and study of ideas (10,6\%)" (Diaz, 2018a: 137).

In its history, Universum has been directed by five signing directors. 
In the two first editions, 1 and $2 \mathrm{~N}^{\circ} 1$, it is Vittorio Di Girolamo who managed the journal between the years 1986-1987. In the editions $2 \mathrm{~N}^{\circ} 2$ and 3, Álvaro Rojas Marín takes the position of director in the years 1987-1988. From there on, Francisco Javier Pinedo managed the journal, excepting for a brief period when he was succeeded by Miguel López Astorga from edition 28, N¹-2013 until edition $31 N^{\circ} 2-2016$ (López, 2013). Francisco Javier Pinedo signs the editorial again in the year 32-2017 Vol. 1 (Pinedo, 2017), and is succeeded in the next issue by Claire Mercier, as subdirector (Mercier, 2017) until $\mathrm{N}^{\circ} 1$ of 2018 (Mercier, 2018). In the second issue of that same year, Mercier signs as director of Universum until today.

Since its foundation, there has been a paragraph of "Presentation" where the director could sign anonymously under the name of their position ("The director"). Nevertheless, the registry of the committee that conformed the journal introduced themselves in the inner cover of every edition (Pinedo, 1996). In 2000, the section "Presentation" is transformed into what is now known as the "Editorial", still plainly signing as "The director" (Pinedo, 2000). In 2004, Francisco Javier Pinedo signs for the first time with his name and position (Pinedo, 2004).

The Universum Journal of Humanities and Social Sciences is indexed in the databases of SciELO since 2005, confirming its commitment to provide with a quality platform for researchers linked to the development of humanities and social sciences (Pinedo, 2005). Afterwards, in 2008, it is indexed in SCOPUS, with the finality of acknowledging the academic relevance of indexation in scientific journals, according to Pinedo himself in an interview (Díaz, 2018b).

Through their official website, http://universum.utalca.cl/ the journal presents a free-access policy to all its historical records, which helps with the diffusion of the information. There are 5 documents that are not in the online registry, but are available in hard copy.

\section{Method}

The present study included an analysis of 765 documents published 
in Universum between the years 1986 and 2017, distributed in 47 issues. The compilation of the documents was made through the journal's own website and the hard copy of the archive, available at the Main Library of the University of Talca, Campus Talca. The method is descriptive, using the published documents (Montero \& León, 2007), through a systematic description of a group of general indicators and indicators associated to the catalogs in which the journal is indexed (Table 1).

In the description of the productivity and collaboration indicators, the article was used as the minimum unit of analysis. In the international collaboration, the nationalities per author in each article have been used as evaluation criterion. Thus, an article can have contributions from more than one country simultaneously. Starting from these components, selected indicators have been evaluated, corresponding to the ones that have been used regularly in the referenced bibliometric studies. In these, the frequency of documents is described according to a group of variables and its respective levels or categories (i.e. 1, 2, 3, 4, 5, 6, 7 authors, sex, language, institution, theme, type, essay, scientific article, review, discourse and pages).

The assigning and recount of the documents have been carried out by a three-peer evaluation and judgment (two of them are the coauthors of this article, plus one external judge), following the double-blind procedure (Devereaux, Manns, Ghali, Quan, Lacchetti, Montori, Bhandari, \& Guyatt, 2001). When there was a disagreement in the classification, this was discussed in a second stage, where it was agreed to choose the most representative category. This procedure has been used for the methodology assignment. Lastly, as a mean to facilitate the description and describe the results, the 32 years of productivity have been divided in four 7-year periods. 


\section{Analyses}

\section{Table 1}

Indicators calculated for this study

Indicators Description

Bibliometric indicators

\begin{abstract}
Amount of documents

Type of documents
\end{abstract}

Language

Institution

Country

Sex

Collaboration indicators

Number of authors Number of signing authors per publication
Amount of document published in the journal between the years 1986-2017.

Type of publication, according to the judge's classifications.

Language in which the corpus of the publication is written.

Name of the associated institution as declared by each author.

Nationality of the associated institution by each author.

Determined by the common gender of the first name of the signing author. 
Lawani Index

Corresponds to the weighted mean of authors per article, distributed by the defined publication periods. It is calculated with the following equation:

$$
\text { Lawani Index }=\frac{\sum_{i=1}^{N} \mathrm{j}_{\mathrm{i}} \mathrm{n}_{j}}{\mathrm{~N}}
$$

where:

$\boldsymbol{N}=$ Total amount of documents (Lawani, 1981; Vinkler, 1993:224).

$\boldsymbol{j}_{\boldsymbol{i}}=$ Frequency of $i$ co-authors in collaboration

$\boldsymbol{n}_{j}=$ amount of documents jpublished in collaboration by i co-authors

There is no maximum value for this index. 
Subramanyam Index Corresponds to the proportion of articles with multiple authors. It is calculated with the following equation:

$$
\text { Subramanyam Index }=\frac{\mathrm{Nm}}{\mathrm{Nm}+\mathrm{Ns}}
$$

where:

$0 \leq$ Subramanyam Index $\leq 1$

$\mathbf{N m}=$ Number of documents with multiple authors published, in a determined period of time.

Ns $=$ Number of documents with a single author published during the same period of time (Subramayan \& Stephens, 1982; Subramanyam, 1983: 37). 
Collaborative Coefficient

Association indicators
Corresponds to the proportion of articles with multiple authors ( 2 or more). It is calculated with the following equation:

$$
\text { Coeficient of Colaboración }=\frac{\sum_{i=1}^{N}\left(\frac{1}{J i}\right) n i j}{\mathrm{~N}}
$$

where:

$\boldsymbol{N}=$ Total number of documents.

$\boldsymbol{J}_{\boldsymbol{i}}=$ Frequency of $i$ co-authors collaborating.

nij= Number of documents $j$ published in collaboration by $i$ co-authors.

Which value oscillates between 0 and 1 , where values close to 0 show a strong presence of documents with only one author (Ajiferuke, Burell, \& Tague, 1988: 424).

Total participation of Corresponds to the number of authors (per nationality

\section{Authors}

First Author

First autor alone or institution) that conform the totality of articles without discriminating by position.

Corresponds to the number of authors (per nationality or institution) that possess the first position in the totality of articles.

Corresponds to the number of authors (per nationality or institution) that participate alone in a publication in the totality of articles. 
Inter-relation Corresponds to the number of authors that participate with the same nationality or institution in one publication.

$$
\text { Inter }- \text { relation }=\frac{\sum_{i=1}^{N}\left(n_{i} \equiv f\right)-\left(n_{i} \neq f\right)}{N}
$$

where:

$N=$ Total number of authors in the article

$\boldsymbol{f}=$ Institution or country of the first author

$\boldsymbol{n}_{\boldsymbol{i}}=$ Number of authors

Which value oscillates between 0 and 1 . Value of 1 shows a national participation and any number below 1 indicates international participation.

Number of relations Corresponds to the association exisiting between the first autor and the rest of the authors from different institutions or countries in the same article.

\section{Results}

Results consider three main aspects of this type of study: productivity, journal and its evolution through time. Moreover, published documents indicators are presented: bibliometric indicators, collaboration, collaborative coefficient and association indicators. 
Figure 1. Indicators of the number of documents per year by type of document. Number of documents produced as: essays, scientific articles, reviews, conferences, master classes, discourses, interviews, semblances o special contributions.

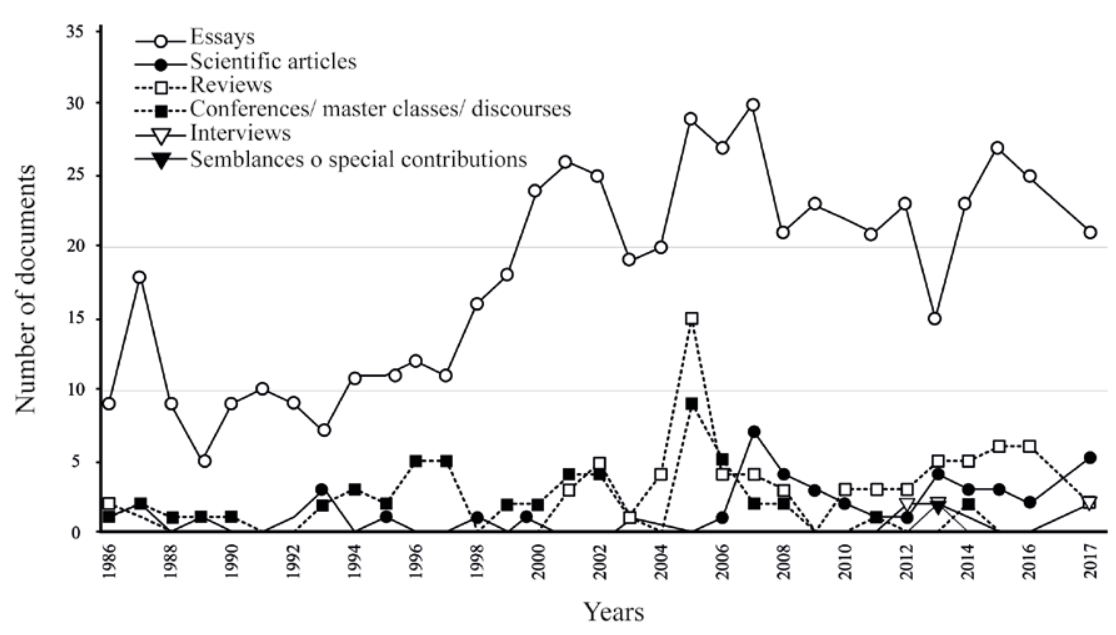

Source: own elaboration

Figure 2. Indicators of the number of documents per year by language. Number of appearances of languages: Spanish, English, Portuguese and French.

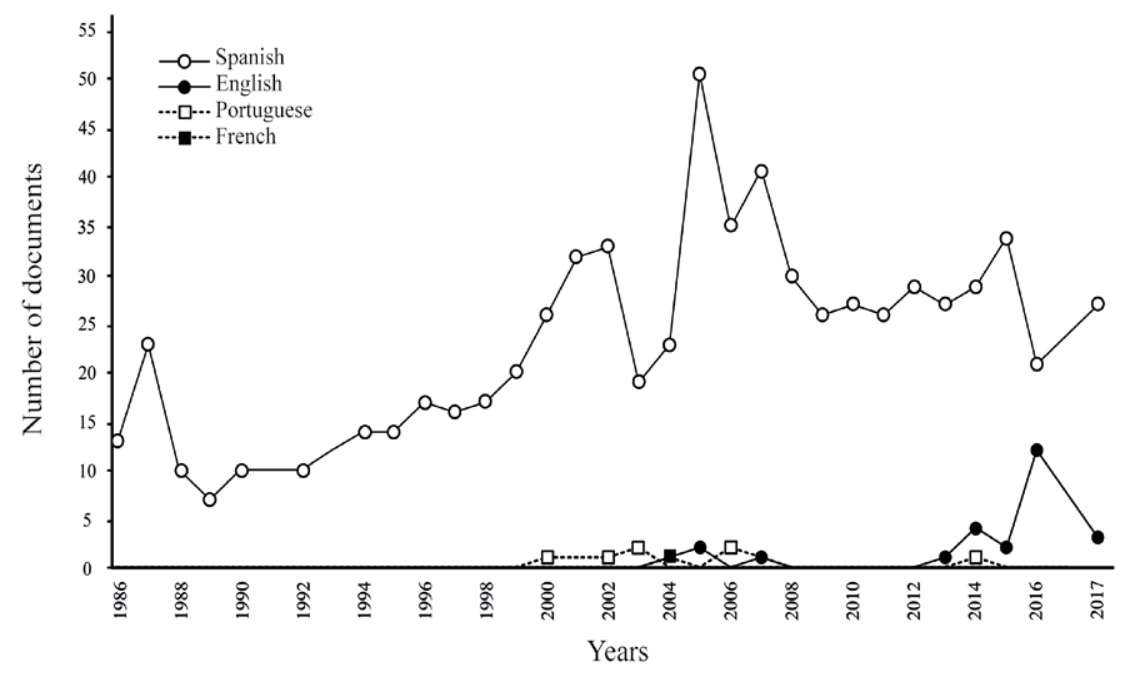

Source: own elaboration 
Figure 3. Indicators of the number of authors per year by sex. Number of appearance of men and women in documents as first author (picture a) and total of authors (picture b).

picture a

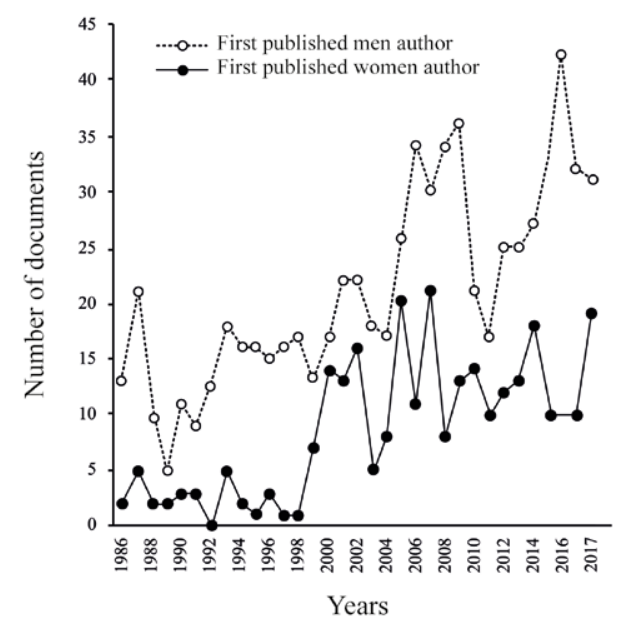

picture $b$

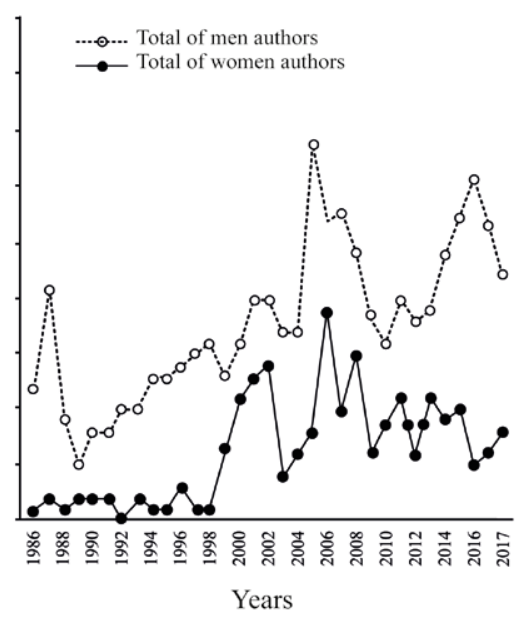

Source: own elaboration

Analyzing the participation of males and females per year, a relevant difference was found in female participation since the founding years (first edition of Universum in 1986). This difference is maintained until 1998 in all publications. In 1999, the first growth of female participation in authorship can be observed. In 2000, the participation of males and females is almost equated, trend that is sustained until 2002. After said year, female participation decreases once more.

This phenomenon can be explained by the incorporation of a new vision in the early 2000: "In that same track, we want to go beyond an integration that allows only the exchange of objects, towards a cultural integration in which we can be involved as representatives of the humanities and social sciences [...] and contribute to develop a civil society that shows a disposition to commit in the support of binational gatherings, and particularly that supports the cultural 
and academic exchange" (Pinedo, 1996: 6). Furthermore, a new section was incorporated to Universum "Latin-American studies network" in that very same year (Pinedo, 1999: 6).

Regarding the total recount of male and female authorship (19862017), 676 male publications can be found, corresponding to the $71.3 \%$, while females have published 272 documents, the $28.6 \%$ of the total sample.

Figure 4 depicts the collaboration among countries in relation to the declared affiliations by the signing authors, and according to the number of national and international documents. This was done by contrasting the main authorship (first declared author) with the rest of the authors (from the second one, according to what has been declared). The country with the largest amount of documents is Chile, with 12 international collaborations, mainly with Argentina, followed by Spain and Germany. It can be observed that these collaborations are infrequent for the most part, thus these publications can be considered isolated events.

Delimitating the sample to publications with Chilean authorship, collaboration nexus among different institutions can be observed. Figure 5 shows the network of collaborations amongst institutions according to the number of documents and collaborations, contrasting the main authorship (first declared author) with the rest of the authors (from the second on, according to what has been declared). The institution with the most documents is University of Talca, with 8 inter-institutional collaborative publications, with: University of Playa Ancha, Martin-Luther Universität Halle-Wittenberg, Cambridge University, the Natural History museum, Pontifical University of Chile, National University of Cuyo, Catholic University of Temuco, University of Los Lagos and University of Santiago of Chile. University of Talca and University of Santiago of Chile have the highest rate of participation, with 210 and 73 documents respectively. 
Table 1: Number of publications by number of authors and period of time.

\begin{tabular}{|c|c|c|c|c|c|}
\hline & \multicolumn{4}{|c|}{ Period } & \multirow{2}{*}{ Total } \\
\hline & $1986-1993$ & $1994-2001$ & 2002-2009 & $2010-2017$ & \\
\hline \multicolumn{6}{|l|}{ Number of authors } \\
\hline 1 & $79(83,2 \%)$ & $148(94 \%)$ & $234(87 \%)$ & $183(75 \%)$ & $517(84 \%)$ \\
\hline $\begin{array}{l}2 \\
3\end{array}$ & $11(11,9 \%)$ & $6(4 \%)$ & $28(10 \%)$ & $35(14 \%)$ & $77(10 \%)$ \\
\hline 4 & $3(3,1 \%)$ & $2(1 \%)$ & $4(1 \%)$ & $18(7 \%)$ & $27(4 \%)$ \\
\hline \multirow[t]{2}{*}{$>4$} & $0(0 \%)$ & $2(1 \%)$ & $3(1 \%)$ & $5(2 \%)$ & $10(1 \%)$ \\
\hline & $2(2,1 \%)$ & $0(0 \%)$ & $0(0 \%)$ & $2(1 \%)$ & $4(1 \%)$ \\
\hline Total & 95 & 158 & 269 & 243 & $765(100 \%)$ \\
\hline \multicolumn{6}{|l|}{ Indexes } \\
\hline G.C. Subramanyam & 0,17 & 0,06 & 0,13 & 0,25 & $0,15^{\mathrm{a}}$ \\
\hline I.C. Lawani & 0,45 & 0,16 & 0,30 & 0,64 & $0,39^{\mathrm{b}}$ \\
\hline $\mathrm{CC}^{\mathrm{c}}$ & 0,11 & 0,04 & 0,08 & 0,17 & 0,10 \\
\hline
\end{tabular}

Note: percentages were calculated over the total per period of time.

a Subramanyam Index obtained by total period of time (1986 - 2017)

${ }^{\mathrm{b}}$ Lawani Index obtained by total period of time (1986 - 2017)

${ }^{\mathrm{c}}$ Collaborative coefficient (cc)

Regarding the quantity of authors per scientific production, it can be observed that the highest percentage of works (84\%) is presented by a single author, while the production of multiple authorship documents has a lower percentage (16\%). Additionally, when different time periods are observed, the production of authors from the first stage (1986-1993) and last stage (20102017) can be contrasted. There is a difference in the quantity of documents received, where the participation of the authors is redistributed, augmenting from $17.1 \%$ to $24 \%$ in the case of multiple authorship, while single author documents diminish from $83.2 \%$ to $75 \%$.

In percentage terms, there is a reduction in the participation of single author. The sample indicates that the quantity of documents received per year has doubled (from 95 to 243), meanwhile, documents from a single author went from 79 to 183 , augmenting in $131 \%$. The documents with multiple 
authorship went from 16 to 60 , increasing in $275 \%{ }^{2}$. Subramanyam index, which calculates the amount of documents with two or more authors over divided by the total amount of documents, reaffirms the growth of multipleauthorship, from a $18 \%$ in the period $1986-1993$ to a $29 \%$ in the period 2010 2017.

Moreover, the Lawani index, which complements the information regarding the multiple authorship of documents by calculating the weighted mean of authors per article in each period, indicates that the increment of collaborations has led to an increased number of multiple authors per document, augmenting from 1, 59 authors in the time period of 1986-1993 to 2, 18 in the period 2010-2017 (see Table 1).

Together, these indexes suggest that not only the number of documents with two or more signing authors has increased, but also the number of signing authors has experienced a rise, as suggested by the collaborating coefficient.

\section{Conclusions}

Universum achieved 32 years of existence with the support of the University of Talca and the Institute of Humanistic Studies "Juan Ignacio Molina". Therefore, studying its characteristics over time is relevant when it comes to make decisions regarding the construction and publication of knowledge from a University that aims to maintain its status in the ranking of best universities in the country.

The journal was conceived in an almost artisanal manner, with its construction being established at an institutional and local level, but aiming to grow immensely. This aim is reflected on the title of the journal, according to Dr. Javier Pinedo, who expresses that the genesis of Universum is conceived as a response from a group of academics that live in a time of "non-humanities", which is in the midst of the Chilean dictatorship. Additionally, a Pinedo mentions that a main feature of the journal is its administration, which has been developed by a group of academics from the University and the women

\footnotetext{
${ }^{2}$ Documentos firmados por uno o más autores; ver Tabla 1.
} 
collaborating in the Institute (Díaz, 2018b), who constantly contributed to push forward the editions of the journal. These characteristics impact directly the way the journal is conducted and its intellectual orientation. We can highlight that, by being a mainly masculine journal, Universum must adopt the new gender equality principles that have arisen from the national feminist movements.

All the previously stated points reflect the necessity of this type of works, which allows to make visible the way science is developed in a written platform. Thus, there is no doubt that the growth of Universum has a direct relation to the relevance of its indexation, which has helped to elevate the impact, category, references and collaborations of this journal. This has given it a relevant place in the humanities and social sciences fields, constituting an academic legitimization space, as it is expressed in the SciELO and SCOPUS indexation.

To summarize, Universum has behaved as a predominantly masculine, national journal, characterized mainly by single-authorship, where the written essay in Spanish is the most prevalent document, and with close, non-extended networks of collaborations. Moreover, although its collaboration index has progressively augmented, it is still a pending task to elevate it even more, as well as equate the contribution of female authors to male authors, and potentiate the publications in foreign languages. Here we leave an invitation to the authors, to work towards an administration and editorial decision-making that may be replicated by other journals in different areas of knowledge. 


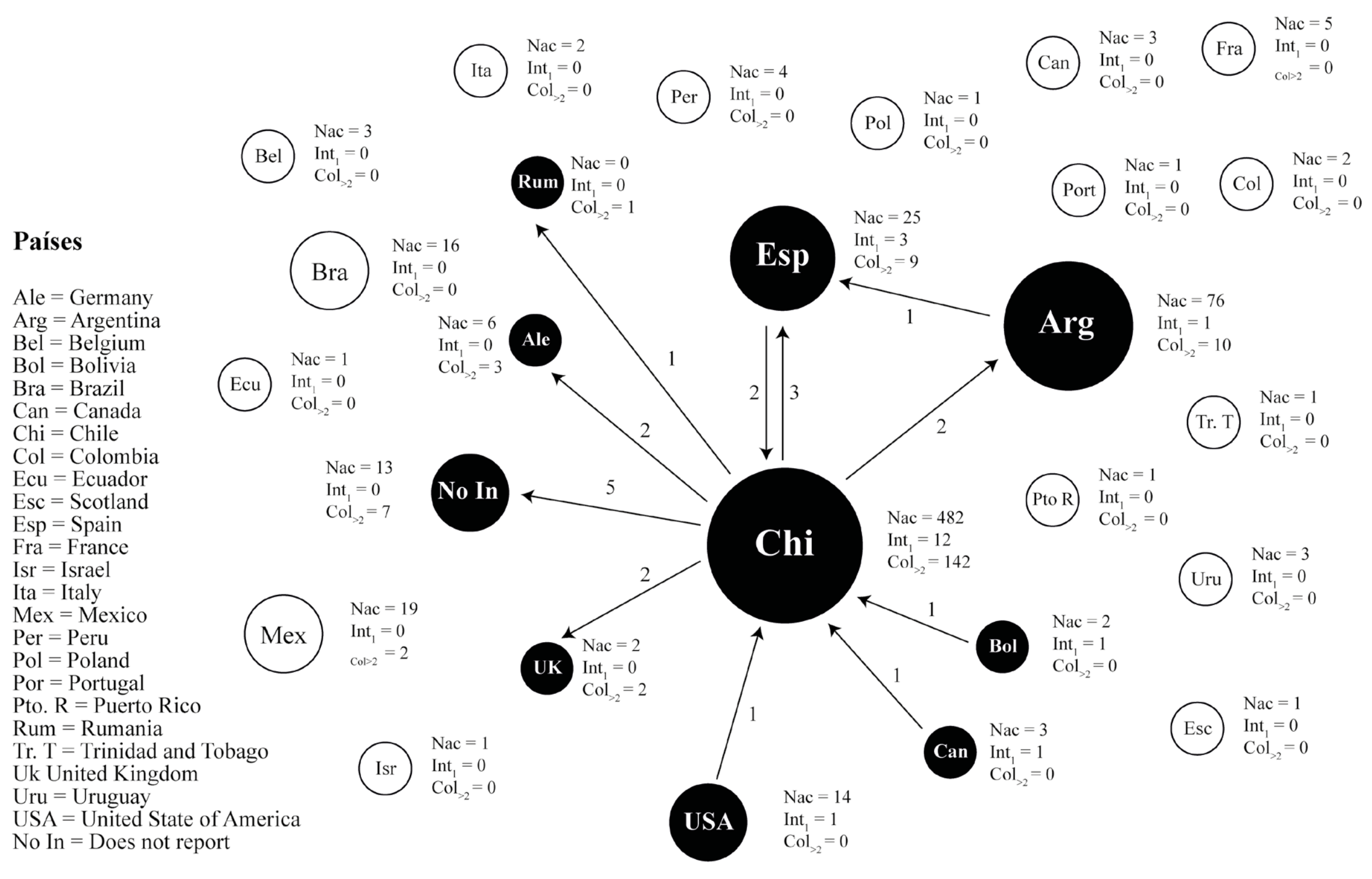

Figure 4. Map of collaboration between countries of the published articles, Own elaboration.

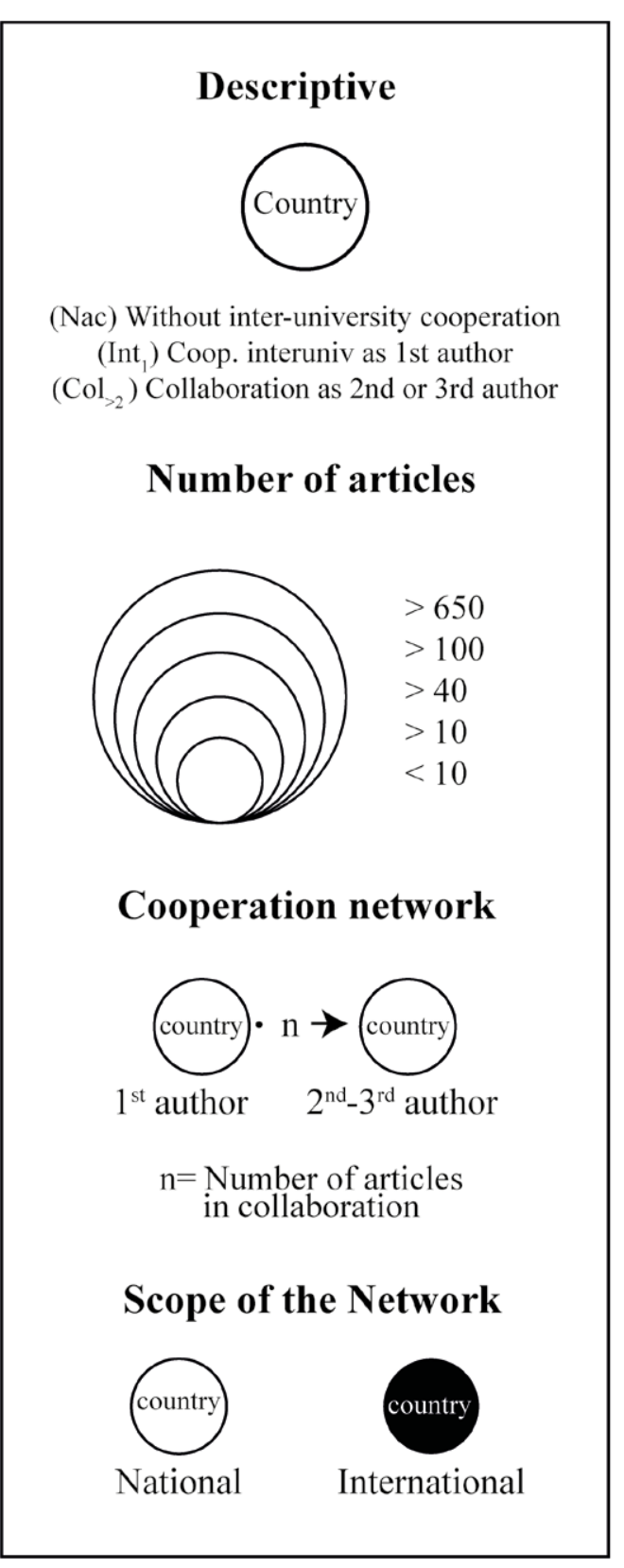




\section{Universities}

Utalca $=$ U. de Talca

Usach $=$ U. de Santiago de Chile

UChile $=$ U.de Chile
PUC $=$ Pontificia U. Católica de Chile

$\mathrm{PUC}=$ Pontificia $\mathrm{U}$. Católice
$\mathrm{UdCon}=\mathrm{U}$. de Concepción

$\mathrm{UDP}=\mathrm{U}$. Diego Portales

$\mathrm{UAH}=\mathrm{U}$. Alberto Hurtado

UPrat $=$ U. Arturo Prat

UCM = U. Católica del Maule

UMCE $=$ U. Metropolitana de Ciencias de la Educació

PAMU $=$ Cambridge Universit

UST $=$ U. Santo Tomás

UML $=$ Universidad Martín Lutero de Halle-Wittenberg

UAuB = Universidad Autónoma de Barcelona

UVall = Universidad de Valladolid

$\mathrm{UCTem}=\mathrm{U}$. Católica de Temuco
$\mathrm{UAHC}=\mathrm{U}$. Academia de Humanismo Cristiano

$\mathrm{UAHC}=\mathrm{U}$. Academia de Hum
$\mathrm{UAB}=\mathrm{U}$. Andrés Bello

UACh $=$ U. Autónoma de Chile

USere $=$ U. de La Serena
ULag $=$ U. de Los Lagos

$\mathrm{UTar}=\mathrm{U}$. de Tarapacá
$\mathrm{UHW}=$ Universidad de Halle Wittenberg

UTs = Universidad de Timisoara
SEECh $=$ Sociedad de Estudios Egiptológicos de Chile

$\mathrm{MHN}=$ Museo de Historia Natura

$\mathrm{UCV}=\mathrm{U}$. Católica de Valparaís

$U \mathrm{CN}=U$. Católica del Norte

UAC $=$. de Los Andes

IMChol = Municipalidad de CholChol

UNC $=$ Universidad Nacional del Comahue

UBB $=$ U. del Bío-Bío

MunTal = Ilustre Municipalidad de Ta

$\mathrm{AnCh}=$ Instituto Antártico Chileno

PUCV $=$ Pontificia U. Católica de Valparaíso
UCCRSH $=$ U. Católica Cardenal Raúl Silva Henríque

UCSC $=$ U.Católica de la Santísima Concepción

UStan $=$ U. de Stanford en Santiago de Chile

$\mathrm{UFT}=\mathrm{U}$. Finis Terrae

UTM $=$ U. Tecnologica Metropolitana

UNCY = Universidad Católica de Cuyo

No In $=$ Does not report

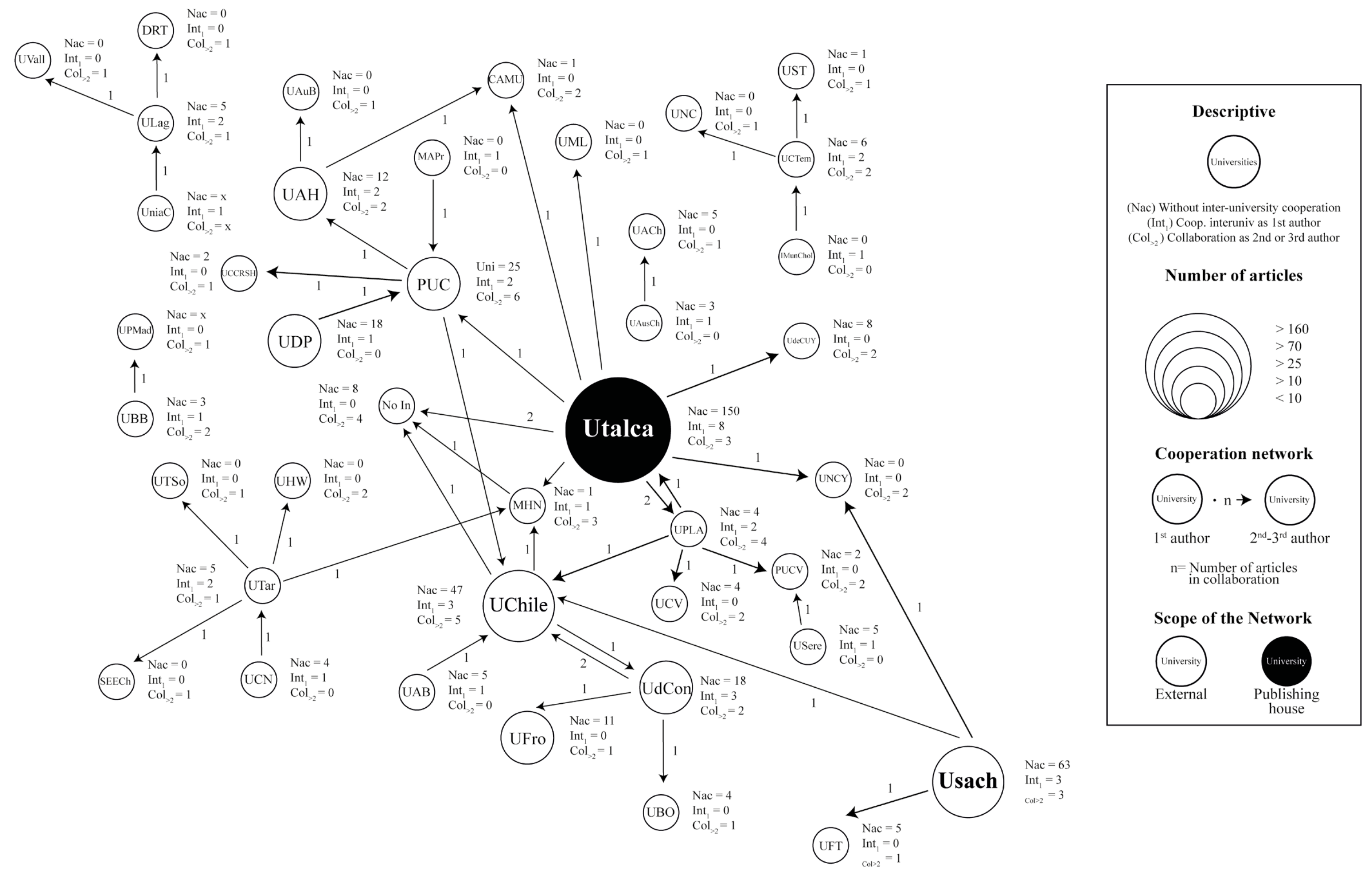

Figure 5. Collaboration map between universities with the first author in Chile in the published articles. Own elaboration. 


\section{References}

Ajiferuke, I.; Burell, Q. \& Tague, J. (1988). “Collaborative coefficient: a single measure Of the degree of collaboration in research". Scientornetrics, 14, 421-433. Disponible en: https://doi.org/10.1007/BF02017100 [Consultado: 20 de diciembre de 2019].

Aleixandre, J.; Bordeu, E.; Aleixandre-Tudó, J.; Bolaños, M. \& AleixandreBenavent, R. (2013). "Scientific productivity and collaboration in viticulture and enology in Latin American countries". Ciencia e Investigación Agraria, 40 (2), 429-443. Disponible en: https:// doi.org/10.4067/S0718-16202013000200017 [Consultado: 20 de diciembre de 2019].

Andrade, D. C.; López, B.; Ramírez-Campillo, R.; Beltrán, R. \& Rodríguez, R. P. (2013). "Bibliometric analysis of South American research in sports science from 1970 to 2012". Motriz: Revista de Educação Física, 19 (4), 783-791. Disponible en: https://doi.org/10.1590/S198065742013000400017 [Consultado: 13 de diciembre de 2018].

Ariza, T., y Granados, M. R. (2012). “Análisis bibliométrico de las revistas iberoamericanas más relevantes afines a la psicología clínica y salud del Journal Citation Reports (2011)". Terapia Psicológica, 30 (3), 89-102. Disponible en: https://doi.org/10.4067/S0718-48082012000300009 [Consultado: 12 de abril de 2019].

Cartes-Velásquez, V.; Moraga, J.; Aravena, P. y Manterola, C. (2012). "Impacto y visibilidad de la Revista Chilena de Cirugía tras su indización en las bases de datos SciELO e ISI: Análisis bibliométrico". Revista Chilena de Cirugía, 64 (6), 511-515. Disponible en: https://doi.org/10.4067/ S0718-40262012000600003 [Consultado: 12 de abril de 2019]. 
Devereaux, P.; Manns, B.; Ghali, W.; Quan, H.; Lacchetti, C.; Montori, V.; Bhandari, M. \& Guyatt, G. (2001). "Physician Interpretations and Textbook Definitions of Blinding Terminology in Randomized Controlled Trials". JAMA, 285 (15), 2000-2003. Disponible en: https:// doi.org/10.1001/jama.285.15.2000 [Consultado: 12 de abril de 2019].

Díaz, C. (2018a). "Investigación cualitativa y análisis de contenido temático. Orientación intelectual de revista Universum". Revista General de Información y Documentación, 28(1). Disponible en: https://doi. org/10.5209/RGID.60813 [Consultado: 12 de abril de 2019].

Díaz, C. (2018b). "No sé cuántas páginas hay ahí, no muchas, pero creo que tenemos algo". Universum, 34 (Número especial homenaje Javier Pinedo), 293-321.

Galán, I.; Pérez-Gómez, B. y Primo-Peña, E. (2015). “QQuién teme al open access? Un movimiento en crecimiento, oportuno y necesario". Gaceta Sanitaria, 29 (2), 139-141. Disponible en: https://doi.org/10.1016/j. gaceta.2014.11.010 [Consultado: 12 de abril de 2019].

Garfield, E. (1955). "Citation Indexes for Science A New Dimension in Documentation through Association of Ideas". Science, 122 (3159), 108-111. Disponible en: https://doi.org/10.1126/science.122.3159.108 [Consultado: 12 de abril de 2019].

Garfield, E. (2006). "The History and Meaning of the Journal Impact Factor". JAMA, 295 (1), 90-93. Disponible en: https://doi.org/10.1001/ jama.295.1.90 [Consultado: 13 de abril de 2019]. 
Garfield, E. (2009). "From the science of science to Scientometrics visualizing the history of science with HistCite software". Journal of Informetrics, 3 (3), 173-179. Disponible en: https://doi.org/10.1016/j.joi.2009.03.009 [Consultado: 13 de abril de 2019].

Girólamo Di, V. (1986). "Editorial”. Universum, 1, 1-3. Disponible en: https:// doi.org/10.13140/RG.2.2.11790.82242 [Consultado: 12 de abril de 2019].

Gross, O. \& Pritchard, A. (1969). "Documentation notes". Journal of Documentation, 25 (4), 348-349. Disponible en: https://doi. org/10.1108/eb026482 [Consultado: 14 de abril de 2019].

Hulme, W. (2015). Statistical Bibliography in Relation to the Growth of Modern Civilization: Two Lectures Delivered I - Scholar's Choice Edition. Creative Media Partners, LLC.

Krauskopf, M. \& Vera, M. I. (1995). "Las revistas latinoamericanas de corriente principal: indicadores y estrategias para su consolidación". Interciencia, 20, 144-148

Krauskopf, E. (2012). "Short Term Impact of the Chilean Journal of Agricultural Research: A Bibliometric Analysis". Chilean Journal of Agricultural Research, 72 (1), 161-164. Disponible en: https://doi.org/10.4067/ S0718-58392012000100026 [Consultado: 13 de abril de 2019].

Lawani, S. M. (1981). "Bibliometrics: Its Theoretical Foundations, Methods and Applications". Libri, 31 (1), 294-315. Disponible en: https://doi. org/10.1515/libr.1981.31.1.294 [Consultado: 13 de abril de 2019].

López, M. (2013). “Editorial”. Universum, 28 (1), 11-14. 
McBride, K. (2009). "Percepciones estudiantiles sobre las técnicas utilizadas en la enseñanza del Inglés como lengua extranjera". Universum. 24 (2), 94-112. Disponible en: http://www.redalyc.org/articulo. oa?id=65027767006 [Consultado: 13 de abril de 2019].

Mercier, C. (2017). "Editorial”. Universum, 32 (2), 11-12.

Mercier, C. (2018). “Editorial”. Universum, 33 (1), 10-12.

Montero, I. \& León, O. G. (2007). "A guide for naming research studies in Psychology". International Journal of Clinical and Health Psychology, 7, 847-862.

Olvera, M. (2016). "La etapa inicial de la Revista Mexicana de Ciencias Políticas y Sociales a 60 años de distancia. Prácticas conmemorativas, legados, olvidos y nuevos pasados/presentes". Revista Mexicana de Ciencias Políticas y Sociales, 61 (226), 427-456. Disponible en: https://doi.org/10.1016/S0185-1918(16)30017-4 [Consultado: 14 de abril de 2019].

Pinedo, F. J. (1996). "Presentación". Universum, 11, 5-6. Disponible en: http://universum.utalca.cl/contenido/index-96/presentacion.html [Consultado: 14 de abril de 2019].

Pinedo, F. J. (1998). "Presentación". Universum, 13 (1), 5-6. Disponible en: http://universum.utalca.cl/contenido/index-98/presentacion.html [Consultado: 14 de abril de 2019].

Pinedo, F. J. (1999). "Presentación”. Universum, 14 (1), 5-6. Disponible en: http://universum.utalca.cl/contenido/index-99/presentacion.html [Consultado: 14 de abril de 2019]. 
Pinedo, F. J. (2000). “Editorial”. Universum, 15, 7-8.

Pinedo, F. J. (2004). “Editorial”. Universum, 19 (1), 7-8.

Pinedo, F. J. (2005). “Editorial”. Universum, 20 (2), 9-10.

Pinedo, F. J. (2017). “Editorial”. Universum, 32 (1), 11-13.

Polanco-Carrasco, R. (2015). "Editora para perturbar". Cuadernos de Neuropsicología / Panamerican Journal of Neuropsychology, 9 (3), 10-11. Disponible en: http://www.redalyc.org/articulo. oa? $\mathrm{id}=439643537001 \% 0 \mathrm{D}$ [Consultado: 14 de abril de 2019].

Reutzel, R. \& Mohr, K. (2015). "50 years of reading Research Quarterly (1965-2014): Looking back, moving forward". Reading Research Quarterly, 50 (1), 13-35. Disponible en: https://doi.org/10.1002/rrq.87 [Consultado: 14 de abril de 2019].

Rodríguez Piña, R. (2006). "Metodología para el análisis de información orientada al análisis de tendencias en el Web superficial a partir de fuentes no estructuradas: Parte I. Fundamentos teóricos". Acimed, 14 (6). Disponible en: http://scielo.sld.cu/scielo.php?script=sci arttext\&pid=S1024-94352006000600005\&lng=es\&tlng=es [Consultado: 14 de abril de 2019].

Salas, G.; Ponce, F.; Méndez-Bustos, P.; Vega-Arce, M.; Pérez, M.; LópezLópez, W. y Cárcamo-Vásquez, H. (2017). "25 Años de Psykhe: Un Análisis Bibliométrico". Psykhe, 26 (1), 1-17. Disponible en: https:// doi.org/10.7764/psykhe.26.1.1205 [Consultado: 14 de abril de 2019]. 
Scimago Journal \& Country Rank. (2018). "Universum". Disponible en: https://www.scimagojr.com/journalsearch. php? $=12100154831 \&$ tip $=$ sid \&clean $=0$ [Consultado: 13 de septiembre de 2018].

Selva, C.; Sahagún, M. y Pallarès, S. (2011). "Estudios sobre Trayectoria Profesional y Acceso de la Mujer a Cargos Directivos: un Análisis Bibliométrico". Revista de Psicología del Trabajo y de las Organizaciones, 27 (3), 227-242. Disponible en: http://scielo.isciii. es/scielo.php?script=sci_abstract\&pid=S1576-59622011000300007 [Consultado: 14 de abril de 2019].

Subramanyam, K.; \& Stephens, E. "Research collaboration and funding in biochemistry and chemical engineering", International Forum on Information and Documentation 7 (4) (1982) 26-29.

Subramanyam, K. "Bibliometric studies of research collaboration: A review", Journal of Information Science (1983) 6-29. Disponible en: https://doi. org/10.1177/016555158300600105 [Consultado: 14 de abril de 2019]

Taylor, F. L. (1948). "Numerical Index Key for the Beilstein System”. Industrial \& Engineering Chemistry, 40 (3), 470-473. Disponible en: https://doi. org/10.1021/ie50459a025 [Consultado: 14 de abril de 2019].

Tomás-Casterá, V.; Sanz-Valero, J. y Wanden-Berghe, C. (2010). "Estudio bibliométrico de la producción científica y uso de la Revista Chilena de Nutrición a través de la red SciELO (2002 a 2007)". Revista Chilena de Nutrición, 37 (3), 330-339. Disponible en: https://doi.org/10.4067/ S0717-75182010000300008 [Consultado: 14 de abril de 2019]. 
Valderrama, J. (2012). "Aspectos éticos en las publicaciones de revistas científicas de corriente principal". Revista Chilena de Pediatría, 83 (5), 417-419. Disponible en: https://doi.org/10.4067/S037041062012000500001 [Consultado: 14 de abril de 2019].

Vinkler,P.(1993). "Research contribution, authorship and team ooperativeness". Scientometrics 26 (1): 213-230

Wren, J. (2005). "Open access and openly accessible: a study of scientific publications shared via the internet". Bmj, 330 (1128). Disponible en: https://doi.org/10.1136/bmj.38422.611736.E0 [Consultado: 14 de abril de 2019]. 